\title{
Putting a Price-Tag on Humanity: Development-Forced Displaced Communities' Fight for More than Just Compensation
}

\author{
Julie Koppel Maldonado
}

\begin{abstract}
The impoverishment commonly associated with development-induced displacement often occurs because of government and development agencies' reliance on compensation as a remedy for resettlement. This study focuses on the inadequacy of compensation use in development-induced forced displacement and resettlement by analyzing 50 recent development projects that involved forced displacement. The aim is for increased understanding leading to action to lessen the impoverishing effects of development-induced displacement.
\end{abstract}

Key words: Development; displacement; resettlement; compensation

Land for land sounds like a reasonable swap, but how do you implement it? How do you uproot 200,000 people....and relocate them in a humane fashion? How do you keep their communities intact?”

- Arundhati Roy (1999:55)

$\mathbf{F}_{\mathrm{f}}$ Torced displacement is not merely physical removal from one's land; it destroys people's lives economically, socially and culturally. Such displacement is often caused by development projects, including dams, mines, roads, irrigation and water supply systems, ports, pipelines, urban infrastructures and special economic zones. Displacement wrecks communities' social structure and leaves those displaced increasingly vulnerable to impoverishment for generations to come. Marginalized communities - rural, urban, farmers and slum-dwellers alike have faced such devastation around the world at increasing rates.

\section{Introduction}

According to current estimates, fifteen million people are displaced worldwide by development projects every year (Cernea 2008b). This means that "every day of every week of every month last decade...some 40,000 more people... became displaced by development programs" (Cernea 2008a:7). Looking at dam-construction alone, the World Commission on Dams assessed, "the overall global level of physical displacement" caused by the construction of large dams "could range from 40 to 80 million [people]" (WCD 2000:104).

In light of the above, my study focuses on the inadequacy of compensation use in development-caused forced displacement and resettlement (DFDR). Social scientists have argued for years that compensation alone does not work in resettling populations and that alternative strategies are needed in addition to compensation. However, the main (and often times only) instrument used by government agencies and project developers to resettle development-induced displaced populations is still to provide cash, land, house and/or in-kind compensation to displaced individuals and families. Because of its significant role in resettling displaced populations, it is important to understand compensation's effects, consequences and inadequacies by documenting the exact problems found with compensation use in DFDR and how it contributes to displacees' impoverishment.

\section{Methodology}

For this study, I analyzed 50 development projects causing forced displacement in Africa, Asia and Latin America, through which I categorized and sorted the problems I found with compensation use in DFDR. I predominantly looked at projects causing displacement between 1997 and 2007 to make my study relevant to current resettlement processes. ${ }^{1}$ The analyzed projects focus on worldwide displacement in development's main sectors - hydropower dams, irrigation projects, extractive industries and infrastructure.

I conducted secondary analysis for my research, reviewing project documents from the major multilateral development agencies, such as the World Bank, private companies and non-governmental and non-profit organizations. In addition, I administered an in-depth questionnaire, surveying nineteen resettlement specialists, researchers and scholars from around the world on compensation use in DFDR, its strengths and weaknesses as a resettlement instrument and alternative solutions. Through my project analysis, I documented the exact problems that occurred with compensation and attest that, despite promises made by project developers, these problems are still very real and all too frequent in today's relocation process.

\section{Findings}

The four major compensation categories used to assist affected communities included: moving compensation, compensation for lost assets, compensation for lost income and compensation for common property resources. Ninety-two percent of the analyzed projects provided compensation for lost assets, just over three-quarters of analyzed projects provided compensation for lost income and only 54\% provided compensation for moving costs. Although some compensation might have been provided for lost assets and lost income, this compensation, if it made it into the recipients' hands, was rarely sufficient for affected individuals and families to avoid increased impoverishment. In fact, almost all of the surveyed experts agreed that compensation for lost assets and lost income is generally inadequate. One problem is insufficient land and/or house compensation, which can be very difficult to assess because these assets might not be privately owned and transactions might not have been recorded. Despite lost asset compensation being inadequate, development agencies 
focus the most on this aspect in the compensation process. This resulted in compensating for lost income, moving costs and common property resources often being overlooked. The most problematic compensation category was common property resources, for which compensation was provided in only half of the projects.

Even though many projects included compensation in the form of cash, land-for-land and/or house replacement, the compensation was typically insufficient to restore and/ or improve resettlers' livelihoods. This was due to the many problems in the process of providing the allotted compensation. For example, delayed compensation payments occurred in $56 \%$ of the analyzed projects, resulting in a significant threat to increased impoverishment for those displaced. According to the Bank Information Center, such delays in payment entail critical consequences for affected individuals and families "who are already suffering from poverty and project-induced vulnerabilities, such as: loss of agricultural land and opportunities, and damages from flooding" (BIC 2003a:2). Due to these delays, people's plans to relocate are delayed because they cannot move until they receive the compensation. They are caught in a state of limbo, unable to move forward, unable to continue where they are.

In addition, $56 \%$ of project-affected communities in this study experienced major problems with under-valuation of assets and 36\% faced problems with asset inventorying. For example, in the Asian Development Bank (ADB)-funded Chashma Irrigation Project in Pakistan, affected individuals asserted that land and asset valuation were marked at about one-tenth to half of the market rate. Lost asset inventorying was severely flawed as well because compensation was not considered for lost agricultural opportunities and destruction of housing, lands and crops due to flooding (BIC 2003a:2).

Forty Two percent of the analyzed projects also had problems with the development agency's data collection, research and survey process to determine who received compensation, as well as some severe discrepancies in the number of people actually affected. Without an accurate assessment of the number of people to be compensated, it is impossible to determine an appropriate budget for compensation and resettlement, thus leading to individuals' further impoverishment. For example, in China's Three Gorges Hydropower Dam Project, 1.4 million people have been resettled so far and another four million are expected to be relocated over the next 10-15 years (MWC 2007:1). Yet, this project's 1991 Resettlement Action Plan, based on a conducted census, indicated that there would only be 725,00o displaced individuals.

Another important aspect of compensation's insufficiency to restore resettlers' livelihoods was the amount given, which tended to be at replacement cost. However, surveyed experts agreed that it is not sufficient to compensate lost assets at replacement cost. Besides the amount, there was also a problem with the quality of the compensation for people's lost assets. Such a problem was exemplified in Brazil's Caña Brava Hydroelectric Power Project, in which the project developer "offered resettlement on lands of poor quality, which will make it impossible for the families to provide for themselves. In other cases, citizens affected by the dam are not being offered any compensation at all" (BIC 2003b:2). This example illustrated the poor condition of replacement land, as well as problems with determining who actually deserved compensation.

Lack of communication between project developers and affected communities, which was found in 54\% of the analyzed projects, was another major problem in determining compensation and resettling those affected. Often time, this lead to violence and stripping of human rights, such as in the case of Sudan's Merowe Dam Project. First, the project authorities did not recognize committees that the affected communities formed to represent their interests. Furthermore, as documented by the International Rivers Network, "The project authorities have responded with violent repression instead of constructive dialogue to the concerns of the affected communities." For example, in April 2006, "militia of the project authority armed with machine guns attacked a large group of affected people who held a peaceful meeting at a school in Amri village. The militia killed three people and wounded 47" (IRN 2007). All this occurred in the aftermath of catastrophic displacement without any communication between project developers and displaced families.

The vast majority of grievances of those affected by the development projects were due to compensation issues, such as delayed payments or insufficient amounts received. When there are misunderstandings about how the grievance system works, individuals are unable to voice their concerns, which increased their risk of impoverishment. Over onequarter of projects analyzed had either no grievance system or had a system that lacked transparency. This was the case in the Three Gorges Dam Project, in which an International Rivers Network (IRN 2003:30) report found that in spite of problems with the project, such as delayed compensation and problems of lost asset valuation, "the government has not established any meaningful, independent grievance procedures. In most cases of conflict, communities have not been able to use the courts to settle their disputes."

\section{Conclusion}

Based on the findings above, it is obvious that there is a great deal to be done to resolve the issues found with compensation to mitigate the impoverishing effects of displacement. The question now remains: where do we go from here?

First, if a development project is seen as an absolute necessity and is going to take place, we need to consider if displacement is necessary for a project's implementation. If displacement is indeed inevitable, then a practical resettlement program needs to precede the project. There are two possible resettlement philosophies to follow, which Michael Cernea described as the property-compensation approach versus the people-centered, development approach. 2 Unfortunately, $86 \%$ of projects in this study still focused on the property-compensation approach, which 
uses compensation as the guiding principle for population resettlement. This strategy, as described in this study, is ineffective and leads to increased impoverishment for those displaced.

There are four components often recognized as the elements needed for a people-centered approach that effectively resettles displaced people and improves their livelihoods. These components are: effective community participation, benefit-sharing, political commitment and will for successful resettlement, and finally, all of these leading to resettlement with development, which is when resettlement is conducted as an opportunity for development for those forcibly displaced, so as to improve their livelihoods after relocation. In addition, there also needs to be adequate social services to provide consultation and assistance to those affected.

These are all viable strategies for improving resettlement, but they are still being ignored while more and more people face displacement and ensuing impoverishment. In fact, only $38 \%$ of the analyzed projects had effective community participation, only $10 \%$ shared a significant amount of project benefits with the displacees, only $34 \%$ showed commitment by the State authorities for successful resettlement and, in only $14 \%$ of the projects, displacees experienced resettlement with development. In line with lack of political commitment to resettlement, there is also a severe lack of national policies that ensure the rights and livelihoods of development forced-displacees are secure. And even when there are such policies, they are often ignored by project developers and governments in the interest of corporate wealth over local human rights.

Without learning from past mistakes, displaced communities will be forced to endure continued catastrophic results. Therefore, when looking at a specific development projects, the questions we must ask are: is the project necessary and what is its purpose? Are marginalized groups sacrificed and suffering for corporate profits and the benefit of the few elite tucked away in urban centers? Or, if the project is truly necessary, how can it be done in such a way that all people benefit, that those forced to sacrifice their homes and way of life are the greatest benefactors, rather than being thrown by the wayside? The political decisions that determine who gains and loses from development need to not only be criticized, but often overturned. Action is needed now to make the changes necessary to mitigate the negative effects experienced by development-caused forced displacement and assure that, if development is necessary, that there is development for all.

Above all, if displacement occurs, resettlers should be better off than they were before displacement and be afforded the human rights that everyone deserves. It is not acceptable for those affected to be denied what is rightfully theirs and pushed further into the margins of society. It is beyond time to not just listen, but truly hear the voices of those displaced screaming for what needs to be done to secure human rights and development for all.
Julie Koppel Maldonado is currently a PhD Anthropology student at American University in Washington DC, focusing on environmental and development-caused displacement.

Corresponding address: jk6582a@student.american.edu

\section{Notes}

1 Some of the projects began before 1997, but are included in this study because there were still people being displaced after 1997. Also, some projects that have yet to be completed are included because the majority of the displacement has already taken place and many of the affected people have been resettled.

2 As discussed in Cernea's 'Development and Displacement' course, George Washington University (Washington DC), November 5, 2007.

\section{References}

BIC, 2003a, BIC Project Factsheet: ADB-funded Chashma Right Bank Irrigation Project III- Pakistan; URL: www.bicusa. org/Legacy/PPA12-Chashma-Right-Bank-Irrigation-PakistanJune-2003.pdf (accessed April 16, 2008).

BIC, 2003b, BIC Project Factsheet: The IDB-funded Caña Brava Hydroelectric Power Project; URL: www.bicusa.org/Legacy/ Cana\%20Brava\%2oPPA.pdf (accessed June 3, 2008).

Cernea, Michael M., 2008a, 'Compensation and investment in resettlement: Theory, practice, pitfalls and needed policy reform', Ch.2 in M.M. Cernea \& H.M. Mathur (eds.), Can Compensation Prevent Impoverishment? Reforming Resettlement through Investments and Benefit-Sharing, London \& New Delhi: Oxford University Press.

Cernea, Michael M., 2008b, Plenary Session Speech, presented to the Society for Applied Anthropology Conference, Memphis, Tennessee, March 26, 2008.

IRN, 2007, Memorandum on the Merowe Dam Project, Berkeley, CA: Leadership Office of the Hamadab Affected People, International Rivers Network; URL: http://internationalrivers. org/en/africa/memorandum-merowe-dam-project (accessed April 16, 2008).

IRN, 2003, Human Rights Dammed Off at Three Gorges: An Investigation of Resettlement and Human Rights Problems in the Three Gorges Dam Project, report prepared by the International Rivers Network, Weed, Urgewald, Berne Declaration and Halifax Initiative; URL: http://internationalrivers.org/files/3gcolor. pdf (accessed April 18, 2008).

MWC, 2007, China Dam to Displace Millions More, Media with Conscience;

url:http://mwcnews.net/content/view/17341\&Itemid=1 (accessed April 2, 2008).

Roy, Arundhati, 1999, The Cost of Living, New York: The Modern Library.

WCD, 2000, Dams and Development: A New Framework for Decision-Making-The Report of the World Commission on Dams, London: Earthscan. 